\title{
The use of early warning scores in clinical practice
}

\author{
Hannah Dahwa
}

Hannah completed her fifth year of medical studies earlier this year at the University of Liverpool. She spent her final two years at Royal Lancaster Infirmary (RLI). As part of her selective in Advanced Medical Practice in the Medical Assessment Unit she performed a systematic review on early warning scores (EWS).

\section{INTRODUCTION}

The aim of this review is to investigate the specificity and sensitivity of EWS trigger points leading to the following outcomes:

- cardiac arrest

- intensive care unit admission

- death

This review will discuss the implications of the studies available in the context of current guidance, and recommendations based on current evidence will be summarised.

\section{The use of EWS in clinical practice}

Patient observations are an objective measure of patient wellbeing. These are recorded on admission and routinely throughout the patient's hospital stay, at least every 12 hours.(I) Measured variables include pulse, respiratory rate, blood pressure, consciousness level, oxygen saturation and temperature. A deterioration of these vital signs is an indication that a patient is becoming unwell and needs review. EWS is designed to increase the recognition of deteriorating patients, ${ }^{(2)}$ and is an example of an aggregate scoring system used nationally, including at RLI. This system is recommended for use by several agencies, including the National Institute for Health and Clinical Excellence ${ }^{(l)}$ and the National Patient Safety Agency. ${ }^{(3)}$

Despite the widespread implementation of EWS, no standardisation has occurred and preset variables may not be appropriate in postoperative patient populations and patients with comorbidities. ${ }^{(4)}$

\section{Guidelines at RLI}

Locally, house officer review is required if the score is above four from multiple categories, three in any one category or there is a high index of clinical suspicion.

The graded response strategy at RLI does not differentiate between patients at medium or high risk.(5) Furthermore, there is no timescale for response to a critically unwell patient; neither is there a trust-wide communication tool for highlighting deteriorating patients. A number of hospital trusts have adopted practices to reduce poor outcomes following an initiative by Patient Safety First, ${ }^{(3)}$ and these are summarised in the appendix.

\section{Components of EWS}

Variations between aggregate scoring systems nationally do not allow accurate comparisons to detect adverse events or measurement of efficacy. ${ }^{(1)}$

A study in 2007 examined the use of EWS for detecting intensive care unit admission, cardiac arrest and death. ${ }^{(6)}$ The review found that sensitivity and positive predictive values of different EWS were low. Based on the data currently available the use of one particular scoring system could not be recommended.

\section{Limitations and alternatives to EWS}

The introduction of scoring systems has improved the amount of data recorded but should not be the sole determinant of clinical decision making. ${ }^{(3)}$ The efficacy of these systems depends on their correct use in clinical practice. Errors such as incomplete or inaccurate charting of scores, failure to intervene, ask for help or increase observations appropriately are common.

An alternative to scoring systems is to rely on 'concern', knowledge of abnormal signs and trends to prompt review. Using clinical judgement in this way leads to inaccurate decisions regarding patient management. ${ }^{(7.8)}$ Decision making can be improved by educating healthcare staff regarding appropriate actions and discussing adverse events. ${ }^{(9)}$

\section{DISCUSSION}

\section{The use of EWS and outcomes on cardiac arrest}

\section{Background: cardiac arrests in-hospital}

The rate of cardiac arrest in-hospital has remained largely unchanged over the last 40 years. Figures show that survivors of in-hospital resuscitation are less than $20 \%$. The majority of cardiac arrests are associated with rhythm disturbances that do not respond to cardioversion and are associated with a poor outcome. Therefore, developing systems to prevent cardiac arrest may lead to improved overall survival by identifying reversible causes. ${ }^{(10)}$

\section{Excluded trials}

In 2005 there was a review of studies assessing medical emergency teams, early warning scores and deterioration prior to cardiac arrest. ${ }^{(4)}$ The authors identify three further studies that are included in this critical appraisal. One study was excluded from analysis. ${ }^{(I)}$ It is not indexed in Medline and could not be obtained directly from the journal referenced.

\section{Discussion of studies using EWS and outcome in cardiac arrest} Two prospective studies were conducted in hospitals in the UK.

One of these studies excluded patients with incomplete pro formas, was conducted over a five-day period and did not exclude patients with 'do not attempt resuscitation' orders. ${ }^{(2)}$ Therefore, data cannot be assessed for effectiveness in clinical practice. In addition, results cannot be generalised to other populations because the data was collected over a short period of time. 
The second study, also an observational study, compared early warning scores of acute medical admissions over a threemonth period. ${ }^{(12)}$ The authors compared results with the other study, conducted during the previous year.(2) The trial was limited because subjects did not undergo standardisation introducing selection bias.

Neither of these trials reported a statistically significant association between increase in early warning score and cardiac arrest.

Information from two trials ${ }^{(13,14)}$ identified by a 2005 study $^{(4)}$ is limited because only abstracts were available from conference proceedings. There was no statistically significant data available that confirms that cardiac arrest is related to higher EWS. Comparison of the data was difficult because trials used different inclusion criteria. In addition, the studies did not adjust for confounders and were conducted at one site introducing selection bias.

\section{The use of EWS and outcomes on intensive care unit (ICU) admission}

\section{Reports reviewing critical care and recommendations}

The Audit Commission examined critical care services across the country establishing that effectiveness between hospitals varied greatly. ${ }^{(15)}$ Shortly after this publication, EWS was developed to identify high-risk patients on the wards. ${ }^{(I)}$ These findings were strengthened by a Department of Health review of critical care services in 2000. ${ }^{(16)}$ They recommended that patients 'at risk' should be clearly identified regardless of location in hospital and intervention should be based on patient need.

Discussion of studies using EWS and outcome on ICU admission In general, studies examining ICU and EWS were similar to those discussed in the previous section. Patient populations varied and most trials did not show a statistically significant correlation of high EWS with cardiac arrests. ${ }^{(2,12,17,18)}$ This could be related to the varying sample size and duration of the study period. Most trials were prospective cohorts that did not standardise patients or prevent confounding thereby introducing selection bias.

The exclusion of data sets that were incomplete, ${ }^{(2,19)}$ awareness and urine output data ${ }^{(2)}$ does not allow these studies to be generalised to clinical practice. A 2007 study demonstrated that modified-EWS and EWS scoring were statistically significant at most time points, 48 hours prior to admission to ICU. ${ }^{(19)}$ In another study, a high sensitivity and specificity of an EWS score of three or more for admission to ICU was established. ${ }^{(20)}$ However, this study did not report the statistical significance of the relationship between admission to ICU and EWS.

\section{The use of EWS and outcomes on mortality Discussion of studies using EWS and outcome on mortality Four trials conducted in general medical admissions were included in this section of the review:}

An audit in 2005 found that poor outcome is significantly associated with an increasing EWS score. ${ }^{(18)}$ In particular, a score of five or more was associated with decreased survival.

A point prevalence study in 2004 examined physiological variables. ${ }^{(21)}$ Unfortunately, this trial did not record EWS but found that more than three abnormal physiological variables were associated with mortality.
One study was performed in a specific subgroup of higher risk patients receiving allogeneic stem cell transplants, thereby greatly limiting external validity. ${ }^{(22)}$ The authors discovered that the cut-off score for patients dying was seven, higher than previous statistically significant estimates of five in an earlier study, ${ }^{(12)}$ described under cardiac arrest. This result was statistically significant, linking EWS to mortality.

\section{CONCLUSION}

\section{Limitations of this review}

There are no randomised controlled trials available to support the use of EWS. Lower quality evidence, mostly cohorts, was examined because few trials were suitable for inclusion. In addition, the data does not represent clinical practice because studies were performed in single centres. Some trials were excluded because they examined EWS only on admission as opposed to hospital stay. This data was excluded in order to make the dataset more homogenous. However, this limited the data available for review and confounded findings.

\section{Search strategy}

More extensive use of resources such as hand-searching, interactive searching of references and contacting authors to clarify data being reviewed would reduce publication bias thereby allowing for a more comprehensive review of the literature. Further searching of databases such as Psychlnfo and CINAHL could have increased the amount of data reviewed.

\section{Evidence base and comparison to local guidelines}

The evidence base for the current guidelines is weak based on the studies included. A large systematic review that includes medical emergency team trigger points summarised most track and trigger systems as having low reliability and validity. ${ }^{(6)}$ Authors suggested that aggregate scoring systems currently in use are not statistically robust. Most of these systems were developed based on clinical judgement and observational studies based in single centres.

The local EWS does not stratify patients as low, medium or high risk. In addition, the policy does not provide clearly validated time frames for intervention. The studies examined do not support the introduction of patient stratification into these discrete groups or a timed response. Five is statistically significant for high risk patients. Locally, a cut-off score of four is already in use and will increase sensitivity at detecting deteriorating patients.

\section{Recommendations for the development of local guidelines}

Rolling education programmes are essential to increase staff awareness of protocols and abnormal physiological values. Systems for effectively communicating information between healthcare staff regarding acutely unwell patients should be implemented as part of the education programme (see appendix). A survey of current staff awareness with regards to abnormal physiological observations could act as a baseline for educational programmes.

Regular audit of observation charts will improve the amount of observations recorded for each patient. This will also encourage better documentation of actions undertaken to address increased EWS and frequency of observations. Recording of ward areas, date, and time of day will assist 
resource allocation. Feedback could be given based on the data to healthcare staff and mortality meetings could identify areas for improvement.

Equipment may be responsible for inaccurate recordings and discrepancies in outcome. The use of equipment to record physiological variables needs to be reviewed and appropriate recommendations provided in order to reduce measurement error.

\section{Further research}

Incomplete charting of data and human calculation errors lead to delays in management. An electronic device recording system for physiological observation will reduce this type of error. Trials investigating the effect on outcome in several centres will allow full evaluation of this technology. It will identify any statistically significant reduction in poor outcomes as a result of increased recording of physiological variables. Systematic poor recording and documentation will be easily identified by electronic devices. This will allow root-cause analysis and provide data for feedback.

EWS is not a prognostic tool. A randomised controlled trial designed to investigate the predictive value of EWS will establish the utility of scoring on admission. The accuracy of each physiological variable at predicting outcome should be assessed. Signs that are more closely correlated with poor outcomes at an early stage should have increased emphasis in scoring criteria.

The use of medical emergency teams is not statistically validated. However, outreach teams offering education, support and ward rounds for at risk patients should be investigated further.

\section{$\mathrm{NHS}$ early warning system}

Physiological observations are time consuming to audit. Moreover, there is no extra funding designated for revision of EWS locally. The current EWS system needs to undergo validation to determine the validity in different patient subgroups, trigger scores and cut-offs for abnormal physiological variables. Currently, a working group from the Royal College of Physicians is developing a national EWS system and will help standardise management of acutely unwell patients. ${ }^{(23)}$

\section{REFERENCES}

I. National Institute of Clinical Excellence. Acutely ill patients in hospital

Available at: http://guidance.nice.org.uk/CG50

(accessed 14 April 2010)

2. Subbe CP, Kruger M, Rutherford P, Gemmel L. Validation of a modified Early Warning Score in medical admissions.

QJM 2001;94(10):521-6

3. Patient Safety First Campaign. Deterioration Available at: http://www.patientsafetyfirst.nhs.uk/ Content.aspx?path=/interventions/Deterioration/ (accessed 14 April 2010)

4. Naeem N, Montenegro $\mathrm{H}$. Beyond the intensive care unit: a review of interventions aimed at anticipating and preventing in-hospital cardiopulmonary arrest. Resuscitation 2005;67( I): 1 3-23
5. The Bedside Clinical Guidelines Partnership. Medical Guidelines 2008-2010. Lancaster: BCGP. 2010

6. Gao H, McDonnell A, Harrison DA, et al. Systematic review and evaluation of physiological track and trigger warning systems for identifying at-risk patients on the ward. Intensive Care Med 2007;33(4):667-79

7. Thompson C, Bucknall T, Estabrookes CA, et al. Nurses' critical event risk assessments: a judgement analysis. J Clin Nurs 2009; | 8(4):60 I- 12

8. Odell M. Are early warning scores the only way to rapidly detect and manage deterioration? Nurs Times 2010;106(8):24-6

9. Priestley G, Watson W, Rashidian A, et al. Introducing Critical Care Outreach: a ward-randomised trial of phased introduction in a general hospital. Intensive Care Med 2004;30(7): 1398-404

10. Resuscitation Council. Prevention of in-hospital cardiac arrest and decisions about cardiopulmonary resuscitation Available at: http://www.resus.org.uk/pages/poihca.pdf (accessed 14 April 2010)

I I. Morgan RJM, Williams F, Wright MM. An early warning scoring system for detecting developing critical illness. Clin Intensive Care 1997;8:100

12. Subbe CP, Davies RG, Williams E, Rutherford P, Gemmell L. Effect of introducing the Modified Early Warning score on clinical outcomes, cardio-pulmonary arrests and intensive care utilisation in acute medical admissions. Anaesthesia 2003;58(8):797-802

13. Stenhouse C, Coates S, Tivey M, Allsop P, Parker T. Prospective evaluation of modified EWS score etc. $\mathrm{Br}$ J Anaesth 2000;84:663

14. Oggioni R, Bandini F, Fradella G, et al. A Bedside Clinical Severity Score To Assess Patients At Risk and To Prevent in-Hospital Cardiac Arrest. Crit Care Med 2004;32(I 2):65

15. Audit Commission. Critical to Success. London: Audit Commission. 1999

16. Department of Health. Comprehensive Critical Care. A Review of Adult Critical Care Services. London: Department of Health. 2000

17. Lam TS, Mak PSK, Siu WS, Lam MY, Cheung TF, Rainer TH. Validation of a Modified Early Warning Score (MEWS) in emergency department observation ward patients. Hong Kong J Emerg Med 2006; I 3(1):24-30

18. Quarterman CP,Thomas AN, McKenna M, McNamee R. Use of a patient information system to audit the introduction of modified early warning scoring. J Eval Clin Pract 2005; I I (2): I33-8

19. Cuthbertson BH, Boroujerdi M, McKie L, Aucott L, Prescott G. Can physiological variables and early warning scoring systems allow early recognition of the deteriorating surgical patient? Crit Care Med 2007;35(2):402-9 
20. Gardner-Thorpe J, Love N, Wrightson J, Walsh S, Keeling N. The value of Modified Early Warning Score (MEWS) in surgical in-patients: a prospective observational study. Ann R Coll Surg Engl 2006;88(6):57I-5

21. Goldhill DR, McNarry AF. Physiological abnormalities in early warning scores are related to mortality in adult inpatients. Br J Anaesth 2004;92(6):882-4
22. von Lilienfeld-Toal M, Midgley K, Lieberbach S, et al. Observation-based early warning scores to detect impending critical illness predict in-hospital and overall survival in patients undergoing allogeneic stem cell transplantation. Biol Blood Marrow Transplant 2007; I 3(5):568-76

23. Royal College of Physicians of London. Acute medical care: the right person, in the right setting - first time. London: RCPL. 2007

\section{APPENDIX}

'Patient safety first' case studies highlighting initiatives for detecting deteriorating patients

\begin{tabular}{|c|c|c|c|c|}
\hline Hospital Trust & Aim & Organisation & Intervention & Outcome \\
\hline $\begin{array}{l}\text { Salford Royal NHS } \\
\text { Foundation Trust } \\
\text { (collaborative working) }\end{array}$ & $\begin{array}{l}\text { Desire to reduce } \\
\text { cardiac arrests by } 50 \% \\
\text { (179 occurred } \\
\text { between } 2007-08 \text { ) }\end{array}$ & $\begin{array}{l}\text { Faculty team for } \\
\text { acutely unwell adults } \\
\text { (AUA) consisting of } \\
\text { healthcare staff } \\
\text { developed in 2008. } \\
\text { Committed to work } \\
\text { together for nine } \\
\text { months and attend } \\
\text { three one-day sessions. } \\
\text { Steering group of } \\
\text { experts formed. } \\
\text { Identified wards with } \\
\text { highest number of } \\
\text { arrests and invited } \\
\text { them to participate. }\end{array}$ & $\begin{array}{l}\text { Evidence for AUA reviewed prior to first } \\
\text { teaching session. } \\
\text { Wards identified problem areas and } \\
\text { developed ideas to deal with these. } \\
\text { Further learning sessions took place, } \\
\text { changes were tested and ideas articulated } \\
\text { to project leaders. Each ward received } \\
\text { monthly cardiac arrest data. Ward teams } \\
\text { presented work to each other. } \\
\text { Acknowledgment in newsletters, days-in- } \\
\text { between certificates and encouraging } \\
\text { publication of ideas to highlight positive } \\
\text { changes. }\end{array}$ & $\begin{array}{l}\text { Empowered and } \\
\text { engaged staff created } \\
\text { changes, not imposed } \\
\text { by management. Used } \\
\text { PDSA (plan do study } \\
\text { act) cycle to minimise } \\
\text { risk in change and } \\
\text { allows weaknesses to } \\
\text { be acknowledged and } \\
\text { redesigned before } \\
\text { widespread use. }\end{array}$ \\
\hline $\begin{array}{l}\text { South Devon NHS } \\
\text { Foundation Trust }\end{array}$ & $\begin{array}{l}15 \% \text { reduction in } \\
\text { hospital mortality } \\
30 \% \text { reduction in } \\
\text { adverse events } \\
30 \% \text { reduction in } \\
\text { cardiac arrests (2006) }\end{array}$ & $\begin{array}{l}\text { The change was } \\
\text { studied by asking } \\
\text { nurses to document } \\
\text { the information } \\
\text { received on transfer } \\
\text { and if it was robust. } \\
\text { Data collated of the } \\
\text { ward and individual } \\
\text { nurse and fed back to } \\
\text { wards. Admitting led } \\
\text { the process of patient } \\
\text { information. }\end{array}$ & $\begin{array}{l}\text { Use of SBAR (situation, background, } \\
\text { assessment and recognition) } \\
\text { communication tool. Posters and stickers } \\
\text { placed in wards, supported by } 10-15 \\
\text { minute teaching and simulated scenarios. } \\
\text { Handover sheets changed to incorporate } \\
\text { SBAR.Telephone referrals to outreach } \\
\text { evaluated and feedback/educational input } \\
\text { given. Regular fortnightly meetings to } \\
\text { discuss issues. Tests of implemented } \\
\text { change performed regularly and changes } \\
\text { implemented based on issues raised at } \\
\text { meetings. Further education given if wards } \\
\text { non-compliant with the change. Initial } \\
\text { concern that SBAR would delay } \\
\text { escalation (especially in arrests). }\end{array}$ & $\begin{array}{l}\text { Handover time reduced } \\
\text { from } 45 \text { to } 7 \text { minutes. } \\
\text { Ownership at ward } \\
\text { level. Core group of } \\
\text { trainers from different } \\
\text { disciplines identified. } \\
\text { (2009) II\% reduction } \\
\text { in hospital mortality } \\
65 \% \text { reduction adverse } \\
\text { events } \\
8 \% \text { reduction cardiac } \\
\text { arrests. }\end{array}$ \\
\hline $\begin{array}{l}\text { Royal Devon and } \\
\text { Exeter NHS } \\
\text { Foundation Trust }\end{array}$ & $\begin{array}{l}\text { Improve handover } \\
\text { process }\end{array}$ & $\begin{array}{l}\text { Used case studies to } \\
\text { illustrate where signs of } \\
\text { deterioration not } \\
\text { detected. Eg, repeatedly } \\
\text { miscalculated low } \\
\text { EWS and same score } \\
\text { repeated, physiological } \\
\text { variables for individual } \\
\text { patients varied, } \\
\text { deteriorating } \\
\text { tachypnoea not } \\
\text { detected as felt it was } \\
\text { normal and not } \\
\text { recorded accurately. }\end{array}$ & $\begin{array}{l}\text { Used an alarm icon to denote patients at } \\
\text { higher risk, creating a visual trigger. Allows } \\
\text { clinical leader to ask questions regarding } \\
\text { care, prompts discussion about placing } \\
\text { patients at risk together to facilitate } \\
\text { nursing and observation. Comment that } \\
\text { other hospitals use predefined variables } \\
\text { for 'acceptable' on the physiological chart, } \\
\text { based on consultant/registrar review of } \\
\text { the notes. }\end{array}$ & $\begin{array}{l}\text { More awareness of } \\
\text { patients at risk, more } \\
\text { attention to regular } \\
\text { observations. } \\
\text { Predetermined } \\
\text { acceptable ranges for } \\
\text { EWS prevents } \\
\text { inaccurate triggers and } \\
\text { improves efficacy. }\end{array}$ \\
\hline
\end{tabular}


APPENDIX - Continued

'Patient safety first' case studies highlighting initiatives for detecting deteriorating patients

\begin{tabular}{|c|c|c|c|c|}
\hline Hospital Trust & Aim & Organisation & Intervention & Outcome \\
\hline $\begin{array}{l}\text { George Eliot Hospital } \\
\text { Trust }\end{array}$ & $\begin{array}{l}2005 \text { - one of the } \\
\text { worst patient safety } \\
\text { records }\end{array}$ & $\begin{array}{l}\text { Associate medical } \\
\text { director now monitors } \\
\text { all cardiac arrest calls } \\
\text { to help reduce in- } \\
\text { hospital mortality by } \\
\text { identifying } \\
\text { deteriorating patients. } \\
\text { Fed back to patient } \\
\text { safety committee and } \\
\text { board if required. } \\
\text { Committee discusses } \\
\text { results and MDT } \\
\text { agrees action. }\end{array}$ & $\begin{array}{l}\text { Intervention started 2008, involving six } \\
\text { areas: } \\
\text { - } \quad \text { physiological observations should be } \\
\text { recorded for all adult patients in acute } \\
\text { settings } \\
\text { - should be recorded and acted on by } \\
\text { trained staff } \\
\text { - } \quad \text { track and trigger system should be } \\
\text { used } \\
\text { - } \text { should be a graded response strategy } \\
\text { - escalation protocol should be in place } \\
\text { - a communication tool should be used } \\
\text { Colour coded patient forms to highlight } \\
\text { current health (red = abnormal; } \\
\text { yellow = leaving normal range; } \\
\text { green = normal). Staff trained in ALERT } \\
\text { courses to improve communication } \\
\text { (SBAR). }\end{array}$ & $\begin{array}{l}\text { Team takes ownership } \\
\text { to ensure changes } \\
\text { identified from poor } \\
\text { recognition of } \\
\text { deteriorating patients } \\
\text { are implemented. } \\
\text { Reduced in-hospital } \\
\text { deaths from I } 26 \text { March } \\
2006 \text { to } 76 \text { May } 2009 . \\
\text { Correctly calculated } \\
\text { EWS } 55 \% \text { October } \\
2006 \text { to } 80 \% \text { May } 2009 . \\
\text { Won patient safety } \\
\text { category Nursing Times } \\
\text { Awards } 2009 \text {. }\end{array}$ \\
\hline $\begin{array}{l}\text { Gateshead Health NHS } \\
\text { Foundation Trust }\end{array}$ & $\begin{array}{l}\text { Improve quality and } \\
\text { frequency of ward } \\
\text { observations }\end{array}$ & $\begin{array}{l}\text { 'Safecare' an internal } \\
\text { branding created to } \\
\text { communicate patient } \\
\text { safety ethos, senior } \\
\text { staff in the trust } \\
\text { establish values. }\end{array}$ & $\begin{array}{l}\text { EWS chart colour coded and actions } \\
\text { included on charts. Obstetric/perinatal } \\
\text { charts being piloted. Critical care outreach } \\
\text { service, extended hours. Education for } \\
\text { qualified staff and healthcare assistants. } \\
\text { SBAR framework used more frequently } \\
\text { and prompts to SBAR. }\end{array}$ & $\begin{array}{l}80 \% \text { EWS scores and } \\
\text { observations charted. } \\
\text { Improvement in } \\
\text { recognition and } \\
\text { response of patients } \\
\text { triggered. }\end{array}$ \\
\hline $\begin{array}{l}\text { Heart of England NHS } \\
\text { Foundation Trust }\end{array}$ & $\begin{array}{l}\text { Reduce harm to } \\
\text { patients (in general) }\end{array}$ & $\begin{array}{l}\text { Patient safety strategy } \\
\text { developed by trust. } \\
\text { Director of medical } \\
\text { safety introduced and } \\
\text { two critical care nurses } \\
\text { made advisors. }\end{array}$ & $\begin{array}{l}\text { The team work to investigate how } \\
\text { incidents occur and to identify trends } \\
\text { across the trust. Baseline assessment of all } \\
\text { safety systems conducted. Extended } \\
\text { critical care outreach to } 24 / 7 . \text { SBAR and } \\
\text { coaching introduced. Barriers to using this } \\
\text { tool investigated. Introduced Global } \\
\text { Trigger Tool. }\end{array}$ & $\begin{array}{l}\text { Improvement in levels } \\
\text { of escalation. Taking first } \\
\text { steps, awaiting review } \\
\text { of interventions. }\end{array}$ \\
\hline Salford Royal & $\begin{array}{l}\text { Improve response to } \\
\text { the acutely unwell }\end{array}$ & $\begin{array}{l}\text { MDT group } \\
\text { investigated rate of } \\
\text { cardiac arrests. Part of } \\
\text { the guidance for } \\
\text { patient safety first was } \\
\text { developed here } \\
\text { following consultation } \\
\text { of doctors to porters. }\end{array}$ & $\begin{array}{l}\text { Installing sphygmomanometer beside } \\
\text { every hospital bed, dictated at ward level. } \\
\text { Tested in I } 2 \text { wards with highest cardiac } \\
\text { arrests. A 'code red' is used to identify } \\
\text { acutely unwell patients so that all staff } \\
\text { look out for that person, identified as a } \\
\text { red spot by the patient's notes in the } \\
\text { nursing station. Nurses are encouraged to } \\
\text { sit patient up, ensure medication is up to } \\
\text { date and put oxygen on if the patient is } \\
\text { unwell. A 'ward round checklist' was } \\
\text { developed to ensure that patients are } \\
\text { reviewed thoroughly. Encouraged } \\
\text { discussion of DNAR. }\end{array}$ & $\begin{array}{l}\text { Contributed to } 30 \% \\
\text { reduction in cardiac } \\
\text { arrests. Greater job } \\
\text { satisfaction for nurses. }\end{array}$ \\
\hline $\begin{array}{l}\text { Royal United Bath } \\
\text { Hospital }\end{array}$ & $\begin{array}{l}100 \% \text { of wards with } \\
\text { correct level of } \\
\text { observations and EWS } \\
\text { charting }\end{array}$ & $\begin{array}{l}\text { Monthly harm event } \\
\text { monitoring identified } \\
\text { EWS recording was } \\
\text { poor. }\end{array}$ & $\begin{array}{l}\text { Auditing EWS scores using productive } \\
\text { audit tool. }\end{array}$ & $\begin{array}{l}96 \% \text { of scores recorded } \\
\text { appropriately and } \\
\text { improved } \\
\text { documentation } \\
\text { regarding frequency of } \\
\text { observations. }\end{array}$ \\
\hline
\end{tabular}

